\title{
Dismantling the 'Lesser Men' and 'Supermen' Myths: US Intelligence on the Imperial Japanese Army after the fall of the Philippines, winter 1942 to spring 1943
}

During the opening stages of the Pacific War, between December 1941 and spring 1942, the Imperial Japanese Army (IJA) appeared unstoppable. US forces in the Philippines, despite their efforts, could not hold out against the enemy advance, and by April, the last vestiges of their resistance at Bataan and Corregidor became untenable. The intelligence obtained during the initial encounters provided the US defense establishment with undeniable reasons to conclude that Japanese ground forces possessed a high level of tactical skill, and assessments of the IJA tended to exaggerate the latter's capabilities.

By the start of 1943, when the Allies had achieved their first victories in the Pacific theaters, and their counter-offensive started to gather momentum, the Americans developed a more optimistic view. Encounters at Guadalcanal and New Guinea proved that the IJA could be defeated, given adequate resources and their methods of use. Nevertheless, in defensive operations, enemy forces proved their skill at inflicting delay and casualties. The Japanese also demonstrated a propensity to fight to the last man and round. US intelligence therefore continued to portray the IJA as an opponent whose martial qualities were not to be downplayed.

For the US Army and Marine Corps, the opening phases of the Pacific War taught them a number of valuable lessons. Military personnel were introduced to the challenges they were to cope with in their campaigns against the Japanese, and were also able to identify some of the ways to conduct successful operations against the IJA. Due attention was paid to the fact that the Allies were fighting an unfamiliar opponent, in battlefield conditions they were not yet accustomed to. The development of appropriate methods against the Japanese hinged upon US forces gaining adequate combat experience.

\section{Historiography}

The existing works on US military operations during the opening stages of the Pacific War provide a detailed account of the way in which the battles unfolded. The official 
histories of the campaigns in the Philippines, Solomon islands and New Guinea have put forward some useful details of how the army and marine corps dealt with the challenges they faced. ${ }^{1}$ A number of unofficial publications have also illustrated the various lessons which were learned from the initial engagements with the IJA. ${ }^{2}$ Nevertheless, the evolution of intelligence assessments of Japanese combat capabilities remains largely unexplored. A number of works have covered US views of the Japanese prior to Pearl Harbor, but they have not explored the way in which opinions of the IJA changed after the outbreak of hostilities. ${ }^{3}$ The scholarship on US army intelligence during the Pacific War has focused on the efforts to decode the IJA's communications. ${ }^{4}$ In regard to American attitudes towards the Japanese, John Dower's seminal monograph illustrated how racial animosity acted as a key influence. ${ }^{5}$ Nevertheless, Dower tends to provide a one-sided account that focuses on public perceptions, and is not clear on the views held by military officials. The following analysis attempts to fill the gap by determining how American views of the IJA developed during the first year following the loss of the Philippines. It examines the nature of the intelligence that was available to the US defense establishment, its methods of scrutinizing the intelligence, and the problems involved in propagating a more calibrated assessment to personnel in the battlefield. Last but not least, one needs to explain how intelligence influenced the development of American tactical doctrine for ground operations.

\footnotetext{
${ }^{1}$ L. Morton, The Fall of the Philippines, J. Miller, Guadalcanal: the first offensive, and S. Milner, Victory in Papua, in series The US Army in World War II: The War in the Pacific (Washington, DC: Historical Division, Department of the Army, 1949-57)

${ }^{2}$ E. Bergerud, Touched With Fire: the land war in the South Pacific (NY: Penguin, 1996); R.B. Frank, Guadalcanal: the definitive account of the landmark battle (NY: Penguin, 1990); L. Mayo, Bloody Buna: the campaign that halted the Japanese invasion of Australia (Garden City, NY: Doubleday \& Co., 1947)

${ }^{3}$ C.L. Christman, 'Franklin D. Roosevelt and the Craft of Strategic Assessment', W. Murray and A.R. Millett (eds), Calculations, Net Assessment and the Coming of World War II (NY: Free Press, 1992), pp.216-57; D. Kahn, 'US Views of Germany and Japan before World War II', E. May (ed.), Knowing One's Enemies: intelligence assessment before the two world wars (Princeton, NJ: Princeton UP, 1984), pp.476-501; also see B. Bidwell, The History of the Military Intelligence Division, Department of the Army General Staff, 1775-1941 (Frederick, MD: University Publications of America, 1986)

${ }^{4}$ E. Drea, MacArthur's ULTRA: codebreaking and the war against Japan, 1942-1945 (Lawrence, KA: Kansas UP, 1992); R. Lewin, The Other ULTRA: codes, cyphers and the defeat of Japan (London: Hutchinson, 1982)

${ }^{5}$ J. Dower, War Without Mercy: race and power in the Pacific War (NY: Pantheon, 1986)
} 


\section{Japanese military effectiveness during the interwar years and early stages of the Pacific War: a worthy match?}

One of the main reasons why US military staffs faced difficulties in assessing the IJA was that its tactical methods and weapons technology demonstrated an uneasy blend of proficiency and backwardness. Even among historians, the Japanese army's performance has attracted both criticism and praise. ${ }^{6}$ On one hand, the IJA's approach to combat was largely focused on the use of the infantry arm, and did not pay a great deal of attention to the importance of employing modern armaments. The idea was based on the experiences of the 1904-05 Russo-Japanese war. ${ }^{7}$ Efforts towards reform were hindered by a number of material and doctrinal factors. During the interwar years, officers studied British, French and German operations during the 1914-18 conflict, and began to explore ways to integrate heavy weaponry such as tanks, artillery and aircraft to their force structures. ${ }^{8}$ However, Japanese industries could not produce large quantities of equipment, and the IJA faced a perpetual problem in procuring an adequate supply.

The material shortcomings were compounded by Japanese doctrine, which was based on the principle that foot soldiers, when properly led and motivated, could overcome whatever technological or numerical advantages their opponents held. ${ }^{9}$ Japan's military culture also stifled initiative, and created a mindset which hindered improvements. Army commanders were imbued with an institutionalized taboo which discouraged them from suggesting that Japanese troops suffered deficiencies that could affect the prospects of victory. ${ }^{10}$ The training of the rank and file was conducted to instill an unquestioned

\footnotetext{
${ }^{6}$ Following analysis is based on A.J. Barker, Japanese Army Handbook, 1939-1945 (London: Ian Allan, 1979); A.D. Coox, Nomonhan: Japan against Russia, 1939 (Stanford: Stanford UP, 1985), and 'The Effectiveness of the Japanese Military Establishment in the Second World War', in A.R. Millett and W. Murray (eds), Military Effectiveness, Volume III: the Second World War, (Boston: Allen \& Unwin, 1988), pp.1-44; E. Drea, In the Service of the Emperor: essays on the Imperial Japanese Army (Lincoln: Nebraska UP, 1998); H.P. Willmott, Empires in the Balance: Japanese and Allied Pacific strategies to April 1942 (Annapolis, MD: Naval Institute Press, 1982).

${ }^{7}$ L.A. Humphreys, The Way of the Heavenly Sword: The Japanese Army in the 1920s (Stanford: Stanford UP, 1995), p.15

${ }^{8}$ Ibid., pp.79-83

${ }^{9}$ Drea, Service of the Emperor, p.63

${ }^{10}$ Coox, 'Effectiveness of the Japanese Military', pp.34-38
} 
acceptance of orders from higher authority, and traditions demanded an adherence to set methods.

Developments following the 1939 border clashes against the Soviets, in the Nomonhan region, highlighted how the IJA's service culture obstructed innovation. The high command realized that its defeat against the Red Army was due to the poor state of its tactics and technology, but the Japanese army's ineptitude in operating armor and artillery prevented it from achieving anything similar to Western standards in the employment of mechanized forces. ${ }^{11}$ The solution was to augment the infantry by introducing a limited amount of supporting arms, but the IJA continued to overestimate the extent to which its forces could cope with enemies who possessed material superiority. Army commanders also continued to hold a condescending view of western forces, including the US and British. ${ }^{12}$

However, the IJA's faults did not significantly affect its performance during the opening stages of the Pacific War. The Japanese defeated opponents who had a clear numerical superiority, and overran Southeast Asia with a mere eleven divisions. ${ }^{13}$ Japanese troops proved to be a tough enemy, 'daring in the attack, and stubborn in the defense'. ${ }^{14}$ Because the bulk of the IJA was drawn from the peasant class, soldiers were accustomed to long hours of hard work, and showed a high level of endurance. ${ }^{15}$ They also held an exceptional level of discipline, and rarely failed to show their willingness to devote themselves to their nation's cause. Last but not least, while the IJA's equipment was below Western standards, infantry units managed to circumvent this weakness by overcoming their opponents with outflanking moves, and using light weapons such as rifles, hand grenades, and mortars.

\footnotetext{
${ }^{11}$ Coox, Nomonhan, pp.1009-32

${ }^{12}$ A.D. Coox, 'Flawed Perception and its Effect Upon Operational Thinking: the case of the Japanese Army, 1937-41', in M. Handel (ed.), Intelligence and Military Operations (London: Frank Cass, 1990), pp.239-54; S. Hayashi, in collaboration with A.D. Coox, Kogun: the Japanese Army in the Pacific War (Quantico, VA: Marine Corps Association, 1959), pp.23-27

${ }^{13}$ Willmott, Empires in the Balance, p.91

${ }^{14}$ Barker, Japanese Army Handbook, p.7

${ }^{15}$ Ibid., p.115
} 
In light of the confusing mixture of strengths and weaknesses, US army officials held an ambivalent view of the IJA, especially prior to the Philippines invasion. The Japanese were recognized for having certain qualities. Within the War Department, the Military Intelligence Division (MID, also designated G-2) was responsible for evaluating the US Army's potential rivals. The MID noted how the IJA had achieved some significant territorial gains during its conflict in China, and emphasized this as an indication that its tactical methods were sound. ${ }^{16}$

The main problem was that US army intelligence did not have an adequate system for disseminating information to decision-makers within the War Department. The MID was not authorized to advise the various services on how to use the intelligence it provided. Reports received from Asia, which were often written by observers who held a negative view of the IJA's performance against the Chinese, were passed to the various branches with minimal elaboration. ${ }^{17}$ The divisions within the War Department, including Operations, rarely made the effort to analyze the material supplied by G-2, because most of them did not have their own intelligence sections until $1940 .{ }^{18}$ As a result, military intelligence rarely received the 'suitable evaluation to the point where [it] could be effectively translated into improvements in [American] tactics, techniques or weapons'. ${ }^{19}$

The War Department thus held a misinformed view of Japanese martial qualities. Most often, assessments were based on the ethnocentric notion which dictated that Western

\footnotetext{
${ }^{16}$ United States National Archives and Records Administration, College Park, MD (NARA 2), RG 226, OSS, Research and Analysis Division, Intelligence Reports, Box 18, War Department, Technical Manual, TM 30-480: Handbook on Japanese Military Forces, 14 May 1941. All documents, unless otherwise stated, were consulted at NARA 2.

${ }^{17}$ For examples, see RG 165, MID Correspondence Relating to Conditions in China, (M-1444), Roll 10, MID 2637-I-276, Report on Military Events by Military Attaché (China), 30 September 1937, and 8 November 1938; RG 165, MID Correspondence relating to conditions in Japan, (M1216), Roll 25, MID 2023-1005, Captain Maxwell D. Taylor (Field Artillery), Tactical Doctrine of the Japanese Army, 1 April 1939

${ }^{18} \mathrm{~W}$. Odom, After the Trenches: the transformation of US Army doctrine, 1919-1939 (College Station, TX: Texas A\&M UP, 1999), p.216

${ }^{19}$ Bidwell, Military Intelligence Division, p.267
} 
forces were superior. ${ }^{20}$ In a memorandum for Secretary of War Henry Stimson, prepared a couple of months prior to the outbreak of hostilities, the War Plans Division (WPD) suggested that the IJA's equipment was 'inferior to that of any of the modern European armies'. ${ }^{21}$ Nevertheless, while racial biases created false perceptions, the fact remained that the Japanese had only fought successfully against weaker opponents such as the Chinese and Russians, and had yet to prove their capability to defeat a more technologically advanced army.

American army staffs also focused on the numerous problems which the IJA faced. US officials were correct in forecasting that the IJA was unable to defeat its Allied opponents in a protracted war. The WPD predicted that the 'shortage of raw materials and production capacity will limit the number of new divisions which can be organized'. ${ }^{22}$ However, prewar assessments overlooked the extent to which Allied forces would initially be in a weak position. According to one estimate, US forces, in cooperation with the British, would stop Japan 'along the general line of Hong Kong, Luzon, and the Pelews'. South of this line, 'the combined ground, air and naval forces of the Associated Powers' were expected to 'exact a tremendous toll'. ${ }^{23}$ The assessment appeared to not acknowledge the fact that the IJA possessed the manpower and equipment needed to successfully execute its initial round of operations in the western Pacific.

Insofar as US army doctrine was concerned, flawed perceptions of the IJA did not contribute significantly to the initial defeats in the Pacific. Instead of intelligence affecting tactical methods, it was usually the US army's doctrine which shaped its benchmarks for gauging the IJA. A key factor which influenced army doctrine was the 'baptism by fire' which western armies experienced during the First World War, which

\footnotetext{
${ }^{20}$ For a parallel account of British perceptions of the IJA before the Pacific War, see J. Ferris, 'Worthy of Some Better Enemy?: the British estimate of the Imperial Japanese Army, and the fall of Singapore, 1919-1941', Canadian Journal of History, Volume 28, No.2 (1993), pp.223-56.

${ }^{21}$ RG 165, War Department, General Staff, War Plans Division, Box 109, File 3251-60, WPD Memorandum for the Secretary of State for War, on Strategic Concept of the Philippine Islands Table A: Combat Estimate, Japan, 7 October 1941

${ }^{22}$ Ibid.

${ }^{23}$ RG 165, War Department, General Staff, WPD, Box 109, File 3251-61, Memorandum for General George Marshall, on Command in the Philippines, 13 October 1941
} 
gave rise to a prevailing belief that future conflicts would be waged primarily through the use of modern equipment. Staff officers from the general service school at Fort Leavenworth stressed the importance of offensive action, and made repeated efforts to enable infantry and artillery to operate in conjunction so as to achieve breakthroughs at critical points along the enemy's defense line. ${ }^{24}$ The drawback to this method was that relied too heavily on heavy weapons, and tended to neglect the important role which infantry units played in conducting the final advance towards enemy positions. Because the Americans concentrated mainly on conducting a combined arms battle, and emphasized the use mechanized units while relegating foot soldiers to a secondary role, the IJA's focus on infantry struck many observers as a backward and outdated practice. Only with proper combat experience, could the Americans formulate a more judicious calculation.

\section{Lessons of defeat}

The intelligence obtained from Southeast Asia during the opening stages of the conflict convinced the Americans that the IJA was capable of putting up an arduous challenge. Within a couple of months following the commencement of the Philippines invasion, military officials discarded virtually all signs of contempt. At the same time, the trauma of defeat gave rise to an exaggerated opinion of the enemy. After the supposedly inferior Japanese army ousted the Allies from Southeast Asia and the western Pacific, the Americans developed a stereotype which portrayed the Japanese as a superman, 'possessed of uncanny discipline and fighting spirit'. ${ }^{25}$ The War Department's intelligence service was not entirely responsible for propagating the so-called 'supermen' myth. On one hand, the military intelligence services in Washington emphasized how the IJA's battlefield performance demonstrated a number of unique strengths, and assessments of the Japanese tended downplay their shortcomings. Yet, the situation was complicated because the War Department's system for intelligence dissemination remained underdeveloped. As a result, military intelligence was unable to effectively

\footnotetext{
${ }^{24}$ Drea, In the Service of the Emperor, pp.61-62, 72-73

${ }^{25}$ Dower, War Without Mercy, p.9
} 
communicate the lessons of defeat to officers at the battlefront. The inflated opinion of the Japanese emanated mainly from army commanders in the Far East, who witnessed their opponent at first hand. Reports from the battlefront showed a propensity to portray the IJA as a formidable opponent which had a number of decisive advantages over the Allies. Nevertheless, the setbacks in Southeast Asia did have a positive impact, in the sense that they led the Americans to take the first steps towards re-evaluating their adversary. Field commanders also realized that if the IJA was to be overcome, the training and efficiency of their own forces needed to undergo significant improvements.

The Japanese invasion of Southeast Asia commenced on 8 December 1941, and by March, the IJA secured Malaya and most of the islands in the Dutch East Indies. While Allied resistance was eliminated by spring 1942, Japanese operational planning showed a number of mistakes, especially in the Philippines. The most notable error was an underestimation of enemy opposition. A month after the invasion commenced, the high command revised its plans, and committed the larger part of its forces to the main objectives in the Dutch East Indies, thereby reducing the size of the invasion force. By early January, the bulk of American forces were confined to their enclave on the Bataan peninsula. General Homma expected to bring the operation 'to an early and successful conclusion'. ${ }^{26}$ Yet, the rugged terrain and thick jungle vegetation did not permit easy movement. Without reinforcements, the IJA was faced with a prolonged campaign, against a resourceful army that 'took full advantage of Japanese errors, miscalculations and over-confidence'. ${ }^{27}$ Nevertheless, the fact that the attack on the Philippines was momentarily stalled seemed irrelevant to most Americans. ${ }^{28}$ As far as US military intelligence was concerned, the Japanese proved their capacity to inflict devastating losses, and Allied forces failed to halt the IJA.

The War Department's Military Intelligence Division went through a metamorphosis during the opening months of the conflict. In winter 1942, following the reorganization of

\footnotetext{
${ }^{26}$ Morton, Fall of the Philippines, p.218

${ }^{27}$ Willmott, Empires in the Balance, p.178

${ }^{28}$ R.H. Spector, The Eagle Against the Sun: the American war with Japan (NY: Vintage Books, 1985), pp.138-39
} 
the War Department, the Military Intelligence Service (MIS) was established, under the direction of the assistant chief of staff, G-2. ${ }^{29}$ The MIS was tasked to disseminate military information, while the MID remained responsible for collection and analysis, as well as formulating the operating policies of army intelligence. Finally in summer 1942, after becoming head of G-2, General George Strong decided that the MIS was to become the chief organization responsible for administering all intelligence activities.

US analysts continued to demonstrate their familiarity with Japanese military practices. Nevertheless, their assessments were inclined to venerate the IJA, without paying due attention to the enemy's faults. For example, the Far Eastern branch of the MID noted how that the IJA's performance suggested that a 'careful [and] meticulous training in all phases of the proposed operation [had] been given to each individual', including rehearsals that simulated actual battle conditions. ${ }^{30}$ Although the Japanese lacked initiative and imagination, their training was 'complete and effective'. The IJA's use of modern weapons was also knowledgeable. In particular, the establishment of air superiority was cited as one of the key reasons for success. ${ }^{31}$ The army air services' tactics and equipment were sufficient for their intended purposes, namely the destruction of Allied airdromes and the provision of close support for ground troops. ${ }^{32}$ Bombing was accurate, with pilots focusing on pre-determined objectives, on which data had been secured through intelligence. Although G-2 had held a respect for the IJA prior to the outbreak of the conflict, the emergence of visible proof that its forces were capable of defeating the Americans led army intelligence to make a more concerted effort to articulate its views.

The MIS also ensured that the intelligence was regularly disseminated through channels

\footnotetext{
${ }^{29}$ Naval War College, Newport, RI, Microfilm Collection, MF 218, US War Department, History of the Military Intelligence Division, 7 December 1941 to 2 September 1945, p.14

${ }^{30}$ RG 165, War Department, G-2 Regional File, Box 2130, File 6000, Far Eastern Branch, MID, The Japanese Army, 31 July 1942

${ }^{31}$ RG 313, Records of Naval Operating Forces, JICPOA, BLUE 644, Box 6, File A8/22c, MID Air Information Bulletin No.3, Timely Tactical Topics II, Undated ?? spring 1942

${ }^{32}$ RG 127, Records of the US Marine Corps, World War II Subject File, Box 25, G-2 section, General Headquarters US Army, Notes on the Japanese Army, 19 December 1942
} 
such as its monthly bulletins, as well as a number of publications, including Tactical and Technical Trends, and Military Reports on the United Nations. The main problem with the setup was that army intelligence staffs in Washington were too removed from the front lines to provide a timely analysis of the lessons learned. Most often, several months lapsed before reports on the Philippines campaign appeared in MIS publications. Only in summer 1942, were US forces in the Southwest Pacific Area (SWPA) and the South Pacific able to rely on a theater-level organization which provided intelligence on the IJA performance. As a result, field commanders had only sporadic access to information on the initial encounters. The problem was compounded by the fact that the vast majority of officers in the Philippines ended up in captivity, and were unable to share their stories with newly-arrived troops. As late as July, following a tour of the SWPA, Major-General Richardson reported to MacArthur that officers in the $32^{\text {nd }}$ and $41^{\text {st }}$ infantry divisions were demanding information on the tactics which the Japanese employed at Bataan. ${ }^{33}$

The formulation of an accurate image was problematic because the US army's intelligence machinery in the Far East fell into disarray during the opening months of the Pacific War. The information emanated from military observers in the Philippines, as well as field commanders who had engaged the IJA. A substantial amount of intelligence was also obtained from the British forces in Malaya, who were bearing a large brunt of the fighting. Although the material provided first-hand accounts of how the Japanese fared against Allied forces, the intelligence machinery did not function smoothly at the levels of analysis and dissemination. General Douglas MacArthur's G-2 section was mainly concerned with quantitative data on the IJA's strengths, dispositions and orders of battle. Military intelligence organizations in the Philippines did not have sufficient resources to process information on the enemy's performance, and as a result, no formal means of communication existed whereby field commanders could propagate their observations.

\footnotetext{
${ }^{33}$ MacArthur Memorial Library and Archive, Norfolk, VA, (MML), RG 29A, Papers of Richard J Marshall, Box 1, Folder 1, Letter from Major-General Robert C Richardson (US Army) to General MacArthur, 4 July 1942
} 
US army officials in the Far East were thus left in a position whereby they had to formulate their own assessments of the IJA. The experiences of defeat provided the Americans with clear indications of the Japanese army’s prowess. In most cases, opinions of the Japanese showed trepidation. Military observers who had previously questioned whether the IJA was a competent force started conceding that the Allies faced a formidable opponent. Observations of Japanese landing operations showed that in this type of warfare, enemy forces operated proficiently. At Kota Baru on the Malay peninsula, the IJA faced heavy counterattacks. ${ }^{34}$ Yet, a sizeable amphibious force reached shore, under cover of darkness. The landing parties often chose unfortified beaches which the defending British forces had considered 'unsuitable', owing to the steep gradient and choppy tidewater. ${ }^{35}$ Rough weather was not an obstacle, and on the contrary, the Japanese deliberately chose such conditions in order to achieve surprise. Once ashore, inland advances were carried out rapidly, without concern for losses.

The IJA's performance on land raised similar levels of fear. Its success in Malaya was attributed to tactical skill. A US observer in Singapore noted how the Japanese showed 'great physical endurance and [an] ability to cross difficult terrain including streams, swamps and jungle'. ${ }^{36}$ Enemy troops also demonstrated ingenuity, by skillfully using disguise and silent movement by night, and advancing via jungle paths and waterways to get behind the British defenses.

In the Philippines, the IJA's infantry arm also demonstrated its aptitude for conducting rapid advances. The Japanese army's ability in the realm of major tactics was considered beyond doubt. Its troops were 'excellently equipped', and 'trained with great

\footnotetext{
${ }^{34}$ L. Barber, 'Pearl Harbor Minus 95 Minutes: Japan's attack on Kota Baru', in Army Quarterly and Defence Journal, Parts I and II, (1995), Volume 125, No.1, pp.5-14, and No.2, pp.138-49

${ }^{35}$ RG 313, Records of Naval Operating Forces, Joint Intelligence Center, Pacific Ocean Areas (JICPOA), BLUE 644, Box 5, File A8/22a, Headquarters, $4^{\text {th }}$ Marines, Intelligence Summary for Period 8 December, 1941 to 1 February 1942, dated 4 February 1942; also see RG 127, Records of the US Marine Corps, World War II Subject File, Box 25, G-2 section, General Headquarters, US Army, Notes on the Japanese Army, 19 December 1941, and 19 February 1942

${ }^{36}$ RG 165, War Department, G-2 Regional File, Box 2146, File 6675, US Military Observer, Singapore, Japanese Tactics and Activities in northern Malaya, 28 December 1941
} 
thoroughness in the hard school of war' as a result of their experiences in China. ${ }^{37}$ Stealth and deception were noted characteristics of enemy tactics. Attacking forces were built up piecemeal so as to avoid detection. Small parties infiltrated the gaps in American defenses, remaining silent, and waited for reinforcements to arrive, until a sufficient force was developed to launch a small attack. ${ }^{38}$ Firecrackers were set off to confuse US troops over the actual location of the attacking force. In other instances, enemy forces withheld their fire with the view to leading the Americans to enter their positions, and then entrapping them with barrages from all directions. ${ }^{39}$ The IJA's capabilities were also aided by a high level of aggressiveness within its rank and file. A report prepared by a former member of the US Military Attaché's staff in Tokyo, based on Japanese commentaries, noted how the most important contributing factor was 'the superb offensive spirit which permeates all of the armed forces of the Empire' ${ }^{40}$

The Japanese also employed their weapons in an adroit manner. The invasion Southeast Asia was characterized by 'mobility, great speed, and reliance on infantry weapons', such as the machine gun and trench mortar. ${ }^{41}$ Commanders did not expend their forces carelessly, and recognized how artillery, tanks and aircraft were necessary for softening Allied defenses and paving the way for the final assault. American personnel, who were often equipped with a limited number of hand grenades and 3-inch mortars with ammunition that contained a high proportion of duds, were overwhelmed by the IJA's material superiority. One commander wrote, 'it was only through maximum effort and determination that we were able to... defend [Bataan] as long as we did’. ${ }^{42}$

\footnotetext{
${ }^{37}$ RG 496, General Headquarters, Southwest Pacific Area (SWPA), Box 281, Allied Land Forces SWPA, Intelligence Summary No.183, 26 June 1942

${ }^{38}$ RG 165, War Department, 'P' File, Box 2313, MIS, Tactical and Technical Trends, No.6, 'Japanese Tactics in the Philippines', 27 August 1942

${ }^{39}$ RG 313, Records of Naval Operating Forces, JICPOA, BLUE 644, Box 5, File A8/22a, Headquarters, $4^{\text {th }}$ Marines, Intelligence Summary for Period 2-20 February, 1942

${ }^{40}$ RG 226, OSS, Research and Analysis Branch Divisions, Intelligence Reports, Box 216, MIS Japanese Land Operations, December 8, 1941 to June 8, 1942, dated 18 November 1942

${ }^{41}$ RG 165, War Department, 'P' File, Box 886, Lieutenant-Colonel Warren J. Clear (GSC), Far Eastern Survey Report, 1942

${ }^{42}$ Morton, Fall of the Philippines, pp.288-89
} 
Although the IJA demonstrated a number of shortcomings, in the aftermath of a devastating setback, US commanders were more likely to expect their opponent to remedy whatever faults it showed. For example, operations were often conducted without sufficient artillery and fire support. At Bataan, heavy artillery fire and armored attacks forced the $14^{\text {th }}$ Army to halt its advance against the Orion-Bagac line. ${ }^{43}$ Nevertheless, the Japanese command persisted, and with the arrival of reinforcements, was able to regroup its forces for a second attempt. US forces, on the other hand, by this time were debilitated and demoralized, while their supplies were reaching the end of their tether. The most important lesson was that the IJA succeeded. Field artillery officers warned against assuming that the Japanese would 'persist in using any system which [did] not produce the best results', and suggested that improvements in their use of heavy weaponry were most likely. ${ }^{44}$ While the opinion overlooked the IJA's difficulties in adjusting its tactics, experiences in the Philippines had demonstrated its propensity to fight effectively.

At the same time, military commanders began to develop a more realistic opinion of the challenges they faced. The development of an image which portrayed the Japanese as an invincible opponent was accompanied by a realization that the US Army's methods needed improvement. Among the most pressing concerns was to prepare more effective defenses against the Japanese. During the withdrawal to Bataan, the assistant head of G-3, US Army Forces the Far East, noted that the defense lines had been hastily and inadequately manned, and ‘not a single position' was 'really occupied and organized' ${ }^{45}$ In order to ensure that their troops could hold out, army officers had to adopt more flexible methods. In the Visayan islands, one commander abided by the traditional doctrine that called for defenses to be concentrated around main roads and positions. ${ }^{46}$ Against the Japanese army's rapid movements, it was necessary to distribute troops and supplies in free flexible detachments, and yet, the idea seemed like 'an abandonment of

\footnotetext{
${ }^{43}$ Ibid., pp.336-46

${ }^{44}$ US Army Military History Institute, Carlisle, PA, (MHI), Field Artillery Journal, 'Japanese Tactics', Parts I and II, March-April 1942

${ }^{45}$ Morton, Fall of the Philippines, p.188

${ }^{46}$ MHI, Papers of Bradford G Chynoweth, The Military Engineer, 'Lessons from the Fall of the Philippines', Volume XLVI, No.313, September-October 1954
} 
the unity and control that had been drilled' into most officers.

US forces also needed to be acclimatized to fight the Japanese in the conditions that prevailed in the Pacific theaters. On one hand, the failure of the IJA's offensive against the Orion-Bagac line made US troops confident in their own fighting abilities. ${ }^{47}$ During the lull in the action, commanders made strenuous efforts to impress upon their troops basic measures such as reconnaissance and patrolling. ${ }^{48}$ Fortifications were improved to provide wider fields of fire and better camouflage. Unfortunately, American forces succumbed to the artillery and aerial bombardment which enemy forces laid down when their operations recommenced. ${ }^{49}$ The upshot of the encounter was that US forces had a significant way to go before they could operate efficiently.

American troops were to be inculcated with the measures they needed to take in order to match their opponent's efficiency. A War Department training manual, based on information obtained by American military observers from British officers in Malaya, warned that the failure to prepare troops for combat conditions in the jungle 'will result in their being surprised both mentally and physically' ${ }^{50}$ Likewise, the Japanese proved that properly trained troops could wrest the tactical initiative, provided they were prepared for the challenges. An infantry officer who served in the Philippines also noted how the morale of troops was unsatisfactory. ${ }^{51}$ Many US soldiers did not harbor the same hatred for the enemy as their Axis counterparts did, and consequently, many of them were killed or taken prisoner. Americans needed to undergo a 'spiritual training' along the lines of the Japanese, and develop a more aggressive attitude. By the middle of 1942, the lessons of defeat led US commanders to discard their pre-war conception, that their forces would prevail against the Japanese in all circumstances. Assessments of the US Army's combat effectiveness vis-à-vis the IJA showed a growing awareness of the shortcomings which needed to be remedied.

\footnotetext{
${ }^{47}$ Morton, Fall of the Philippines, pp.350-51

${ }^{48}$ Ibid., pp.408-10

${ }^{49}$ Ibid., pp.418-19, 438-39

${ }^{50}$ MHI, War Department, Training Circular No.55: Notes on Jungle Warfare, 18 August 1942

${ }^{51}$ MHI, Infantry Journal, 'Lessons of Bataan', by Colonel Milton A. Hill, October 1942
} 
Japanese martial qualities were not the only feature that required reassessment. Equally important was to gain a better knowledge regarding the characteristics of the enemy which the Americans were fighting, and to determine the underlying factors which influenced the IJA's performance. Again, the situation was complicated because US officials had for a long time held stereotyped opinions of the Japanese. Their perceptions reflected a view held by Western intellectual circles for centuries, namely that Asian traditions and cultural values were at great variance with their western counterparts, almost to the point where they were inscrutable. ${ }^{52}$ During the initial stages of the conflict, when the IJA appeared almost unbeatable, the Americans were more likely to focus on the ideological fervor which their enemy had demonstrated.

The situation was further complicated because the Americans were engaging an unfamiliar opponent. Oftentimes, conclusions were based on myopic judgments, and the Americans tended to describe the Japanese as a barbaric race. Furthermore, the trauma of defeat gave rise to a hatred for the enemy, which in turn created an attitude of contempt. Army intelligence alleged that the Japanese were a people devoid of ethical principles. In April 1942, a bulletin issued by Western Defense Command and the $4^{\text {th }}$ Army concluded that the Japanese 'have no code of morals', and were thus capable of an exceptional level of treachery. ${ }^{53} \mathrm{~A}$ former military attaché in Tokyo explained, 'one can only understand the "bestial savagery" of the Japanese by a glance into their history'. ${ }^{54}$ Centuries of internecine warfare had rendered their country a battlefield, where it was accepted practice to sacrifice one's life for the clan. Modern Japan was driven by a similar type of 'primeval stoicism'.

Army intelligence did attempt to dismantle the 'supermen' and 'primitive savage' images.

\footnotetext{
${ }^{52}$ Dower, War Without Mercy, pp.94-99

${ }^{53}$ RG 407, Records of the Adjutant General's Office (AGO), World War II Operations Reports, Box 10078, File 337-2.17, Headquarters Western Defense Command and $4^{\text {th }}$ Army (Office of the Assistant Chief of Staff, G-2, Presidio of San Francisco), Psychology of the Japanese Soldier, 27 April 1942

${ }^{54}$ MHI, Infantry Journal, 'Close-up of the Japanese Fighting Man', by Lieutenant-Colonel Warren J. Clear, November 1942
} 
Nevertheless, the MIS still harped on the fact that the enemy had a distinctive set of values. The Japanese had been educated to believe that their nation was destined to win the war, and when this belief proved to be false as their forces began to face defeat, enemy troops were more likely to commit suicide out of confusion and desperation. ${ }^{55}$ The opinion tended to put forward a one-sided view of the Japanese character. The intellectual qualities of the Japanese were also a target for criticism. Despite the proven capacity to carry out complicated operations, Japan's cultural development was still directly imported from China, while technological advances were dependent on Western influence. ${ }^{56}$ Imitation was one thus an 'inherent characteristic', and this rendered the Japanese to be lacking in any sense of creativity.

Once the shock of the initial defeats subsided, army intelligence staffs formulated more rational opinions. A realistic understanding of the enemy was considered necessary if the US army establishment was to avoid developing distorted views, which in turn could lead to further setbacks. The Japanese were credited for having features aside from a blind fanaticism. In May 1942, the Advanced Echelon Headquarters at Honolulu issued a pamphlet, which noted how every move the IJA made in the war had 'demonstrated long range planning and detailed study of the opponent [they] expected to fight'. ${ }^{57}$ Military intelligence also attempted to explain the features which influenced the Japanese soldier's behavior. The Far Eastern branch issued a study which stated how morale and military spirit (seishin) were traditionally the foundations for the Japanese soldier's training. ${ }^{58}$ Seishin was 'responsible for the superb offensive spirit with which the Japanese army has always been so strongly imbued', and it stemmed from a strong belief in their 'divine mission'. The Japanese were not 'a race of imitators', but had developed a way of

\footnotetext{
${ }^{55}$ RG 127, Records of the US Marine Corps, World War II Subject File, Box 25, G-2 section, General Headquarters, US Army, Notes on the Japanese Army, 19 December 1941

${ }^{56}$ RG 165, War Department, G-2 Regional File, Box 2052, File 2100, Board of Economic Warfare, Far Eastern Division, Japan's Adoption of Western Technology: methods by which Japan acquired modern industrial techniques, Undated ?? spring 1942

${ }^{57}$ RG 313, Records of Naval Operating Forces, JICPOA, BLUE 644, Box 6, File A8/23, Advance Echelon Headquarters, (Honolulu), Intelligence Memorandum, Japanese Weapons and Tactics, 2 May 1942

${ }^{58}$ RG 165, War Department, G-2 Regional File, Box 2147, File 6675, Far Eastern Branch, MIS, Training in the Japanese Army, 30 September 1942
} 
fighting that was based on their own experiences. Thus, by mid-1942, intelligence staffs made an earnest effort to properly gauge the IJA's unique characteristics, and propagate a less prejudiced view.

\section{Limited victories in the Pacific, autumn 1942 to winter 1943: the myth of invincibility dismantled}

During late 1942 and winter 1943, Allied forces conducted a number of successful operations against the outer perimeter of Japan's empire. The US Marine Corps, along with the $25^{\text {th }}$ Infantry Division, halted the conquest of Guadalcanal in the Solomon Islands, which the Japanese had attempted to secure as a base for disrupting Allied shipping lines in the South Pacific. By February 1943, the remaining Japanese forces withdrew from the island. Meanwhile, in New Guinea, the US Army, in conjunction with the Australians, checked the IJA's advance against Port Moresby, and prevented the Japanese from acquiring a base that could be used for an invasion of Australia. General MacArthur ordered an operation to secure the eastern portion of New Guinea, and in early January, enemy forces were ousted from their beachheads in the Buna-Gona area. The intelligence obtained through the encounters convinced both the MIS and its Marine Corps counterpart that the Japanese were not invincible as they previously appeared, and the IJA possessed shortcomings which adversely affected its fighting capabilities. The most notable fault was the shortage of modern weapons, and a lack of skill in their use. At the same time, intelligence staffs warned that the IJA was by no means an easy opponent. In offensive and defensive operations alike, the Japanese remained capable of inflicting substantial attrition and casualties.

By summer 1942, the Americans established a more elaborate theater-level intelligence machinery in the Pacific. The intelligence arrived in three main forms. While combat action reports were the most important source, captured documents and POW interrogations became increasingly available as the campaigns progressed. Each zone of command, including the Central Pacific, South Pacific, and SWPA, had its own central intelligence organization. (see map) The Joint Intelligence Center (JICPOA), with its headquarters at Honolulu, was responsible for the Central Pacific. In the South Pacific, 
the Combat Intelligence Center had jurisdiction over POW interrogations and captured documents, while the Headquarters of the US Army Forces (USAFISPA), based at Noumea, New Caledonia, processed reports on the IJA's performance. Similar arrangements were set up in the SWPA. The Allied Translation and Interrogation Service (ATIS) was an inter-allied organization, comprised of intelligence officials from the US, Australia and Great Britain, although the former two were the overwhelmingly major actors. A similar set-up existed within Headquarters Allied Land Forces The Marine Corps also had their own organizations for processing information on the IJA, both at their headquarters in Washington and main Pacific base at San Diego. In the South Pacific theater, each marine division had its own intelligence section.

The main problem with the intelligence effort in the Pacific theaters was that initially, the Americans did not have a great deal of material to formulate an accurate assessment. US forces had little experience in conducting offensive operations against the IJA, and most units entered combat without a full knowledge of the challenges they faced. Information bulletins produced by the MIS, as well as the theater-level intelligence organizations, contained little information on Japanese defensive methods until the final months of 1942. In any case, military personnel were often isolated from MIS publications, or reports of any type, mainly because the Allied transport system was overburdened with the shipment of supplies and ammunition. Marines at Guadalcanal received 'no formal indoctrination' on Japanese combat methods. ${ }^{59}$

The problem was further complicated because no formal means existed for sharing intelligence between the various theaters. The Navy and Army had ultimate control over specific areas, with the Navy in charge of the Central and South Pacific, and the Army commanding the SWPA. Inter-service rivalries prevented dissemination, and the War Department thus needed to remain as the clearing house for IJA-related intelligence. The arrangement caused delays in dissemination.

Despite the problems, by the latter part of 1942, the Americans began to develop a

\footnotetext{
${ }^{59}$ Bergerud, Touched with Fire, p.405
} 
balanced understanding of the Japanese. The passage of time since the fall of the Philippines provided an opportunity to digest the lessons learned. The MIS showed a more objective opinion of why the Japanese managed to conquer Southeast Asia. The IJA's early successes were attributable to the unprepared state of its enemies. Outflanking and infiltration movements were successful mainly because the Japanese 'had the most troops and complete air superiority'. ${ }^{60}$ Enemy forces also had not developed any 'brandnew tactics or new super weapons', while their tactical methods were no different from those employed by other modern armies. For example, Japanese principles for infiltration movements were 'practically the same' as those set forth in the US Army's basic manual on jungle warfare.

Encounters against Japanese forces in the Solomons and New Guinea showed persuasive evidence that they could be beaten by properly equipped and trained troops. The IJA's performance also started to reveal flaws that precluded it from fighting successfully. A noted weakness was the over-reliance on infantry, and an apparent inability to comprehend the destructive potential of modern firepower. In his report on the second phase of he Guadalcanal operation, General Vandegrift, commander of the $1^{\text {st }}$ Marine Division, suggested that the IJA's earlier successes had 'induced a state of contempt for [the Allies'] capacity and willingness to fight'. During the attack on Henderson field, the Ichiki detachment made repeated assaults on positions defended by machine gun and barbed wire, and persisted even after entire units had been annihilated. The encounter demonstrated how enemy troops were 'utterly incapable, intellectually or morally, of meeting the requirements of modern warfare' ${ }^{61}$ Army intelligence also concluded that Japanese forces performed poorly because they held flawed ideas on how to conduct warfare. JICPOA explained how the IJA tended to over-emphasize martial spirit and bravery. The philosophy was 'the cause for the scorn which they [had] for [Allied]

${ }^{60}$ RG 165, War Department, 'P' File, Box 1203, MIS, Intelligence Bulletin, Volume 1, No.1, Part 2: Japan, Section 1: Ground Forces, September 1942

${ }^{61}$ RG 496, General Headquarters, SWPA, Box 731, Division Commander's Final Report on Guadalcanal Operation, Phase IV, (undated, ?? autumn 1942). For details of the encounter, see Miller, Guadalcanal, p.93; J. Costello, The Pacific War, 1941-1945 (NY: Rawson-Wade, 1981), pp.356-57 
machines of war and fighting ability'. ${ }^{62}$ The belief of the infantry being 'almighty' proved incorrect in the South Pacific. Yet, the Japanese appeared to be at a loss for ways to remedy their faults.

At the same time, the Americans were wary not to lapse into over-optimism, and acknowledged how Japanese forces still possessed certain characteristics that rendered them difficult to defeat. US troops in the Pacific continued to report that their enemy made good use of their infantry units and small arms. ${ }^{63}$ Snipers caused anxieties for Allied soldiers, and whenever a field of fire existed, enemy troops climbed trees, sometimes remaining undetected for days. ${ }^{64}$ As late as 1942, the MIS reiterated its contention that, owing to the durability of its infantry, the Japanese army was a 'wellorganized, trained and equipped' force. ${ }^{65}$

Although Allied forces managed to repel enemy offensives, the Japanese maintained a high level of dexterity. Speed and surprise continued to be key features. Troops were issued with detailed instructions to gain comprehensive information on their targets. At Guadalcanal, the plan of attack called for front-line infiltration units to undertake a full reconnaissance of enemy forces, and keep their activities and dispositions 'under continuous observation'. ${ }^{66}$ During their attacks against Australian positions along the Kokoda trail, the Japanese used feint shots and battle cries to compel the defenders to fire back and disclose their positions. Upon discovering a soft spot, the Japanese launched a series of continuous advances. Consequently, it was dangerous for the Allies to weaken the point of attack to reinforce other zones where Japanese troops had infiltrated. ${ }^{67}$ The

\footnotetext{
${ }^{62}$ RG 165, War Department, 'P’ File, Box 472, JICPOA, Bulletin 12-43, Japanese Land Forces, No.6, 18 February 1943

${ }^{63}$ Bergerud, Touched with Fire, pp.288-89

${ }^{64}$ Ibid., pp.356-59

${ }^{65}$ RG 165, War Department, G-2 Regional File, Box 2130, File 6000, Comments on the efficiency of the Japanese Army, 27 November 1942

${ }^{66}$ United Kingdom National Archives, Kew, London, (UKNA) WO 208/1385, Combat Intelligence Centre, South Pacific, Collected Plan for Capture of Guadalcanal, document collected by Second Marine Division, taken in January or February 1943

${ }^{67}$ RG 165, War Department, 'P' File, Box 2313, MIS, Tactical and Technical Trends, No.23, 'Fighting on the Kokoda Trail in New Guinea', 22 April 1943
} 
Australians eventually found it impossible to make a stand because they were outnumbered and short on ammunition. At Milne Bay, Japanese scouts used the cover of vegetation to conceal their movements, and approached the Allied positions virtually undetected. $^{68}$

Observers in the Solomon islands continued to stress the infiltration tactics which the Japanese used. On a number of occasions, enemy troops managed to cut off the US Marines' outposts, and destroyed a large part of their equipment, while inflicting heavy casualties. ${ }^{69}$ Infiltration movements were 'carried on so extensively' that the Japanese were 'able to outnumber enemy positions at will' ${ }^{70}$

In spite of their shortage of fire support, the Japanese periodically effected a good degree of cooperation between their arms. During the attack on Sanananda in New Guinea, fighters came in just over the trees, dived towards the airdrome, and after machine gunning the grounded aircraft and anti-aircraft emplacements, flew in circles to observe the results of the attack. ${ }^{71}$

In defensive operations, the IJA put up significant obstacles. As was the case on the offensive, Japanese troops demonstrated their skill in screening their presence. Sergeant D.L. Golden, from the $164^{\text {th }}$ infantry battalion at Guadalcanal, remarked that 'Japanese camouflage was miles ahead' of the Americans. ${ }^{72}$ US troops often did not notice a defense until they were within ten to fifteen yards, and the only warning was the appearance of enemy fire.

${ }^{68}$ UKNA, WO 208/2263, War Office, Weekly Intelligence Summary, (hereafter, WOWIS), No.183, 'Extract from Report on Operations, Milne Bay, 24 August to 8 September 1942' (Issued by Allied Land Headquarters, SWPA, dated 8 October 1942), 17 February 1943

${ }^{69}$ RG 165, War Department, 'P' File, Box 1203, MIS, Intelligence Bulletin, Volume 1, No.4, Part 1: Japan, Section 1: Fighting in the Solomon islands, December 1942

${ }^{70}$ RG 494, US Army Forces in the Middle Pacific (MIDPAC), Box 64, Assistant Chief of Staff, G-2, Notes on the Solomon Islands as gathered from evacuated casualties, Part II, 'Roses', (undated ?? 1942)

${ }^{71}$ RG 494, MIDPAC, Box 46, Far East Branch, Air Group, MIS, Notes on Japanese Air Tactics, 3 August 1942

${ }^{72}$ MML, RG 30, Papers of Richard K Sutherland, Box 26, Folder 12, Government Printing Office, Fighting on Guadalcanal, Commentary by Sergeant D.L. Golden, $164^{\text {th }}$ Infantry, 1943 
Japanese positions were constructed to hold out against attacks by forces with numerical and material superiority. Bunkers were designed to withstand the effects of heavy bombardment. At the Mount Austen area on Guadalcanal, the 25th infantry division found that mortar fire did little damage to enemy pill-boxes, while howitzers could achieve results only with a direct hit. ${ }^{73}$ At Buna, the Japanese displayed an energy in preparing their positions that was in 'sharp contrast to the laziness and indifference of many of the small American units in constructing field fortifications' ${ }^{74}$ A series of mutually-supporting bunkers was constructed, connected by fire trenches that were 'a constant source of trouble'. Local materials such as palm logs, dirt and sand were arranged in alternate layers, to give full protection against bombardment. ${ }^{75}$ Against such defenses, artillery, ordinary grenades, mortar fire and aerial attacks were 'completely ineffective'. ${ }^{76}$ Enemy defenses also commanded wide fields of fire. One officer lamented, 'our troops were pinned down everywhere... It was dangerous to show even a finger from behind one's cover, as it would immediately draw a burst of fire' ${ }^{77}$ Extensive use was also made of the terrain in order to restrict the possible approaches. Positions were built on high ground, and as late as three days before the fall of Buna, General Robert Eichelberger, then commanding the I Corps, pondered, 'even those few corridors which exist are narrowed by swamps and woods so that our maneuver is terrifically restricted' ${ }^{78}$

Japanese troops also continued to show a high level of discipline. A War Department technical manual, issued in September 1942, described enemy morale as 'excellent'. ${ }^{79}$ The fighting abilities of Japanese troops were by no means seamless. One of the most

\footnotetext{
${ }^{73}$ Miller, Guadalcanal, p.244

${ }^{74}$ RG 165, War Department, G-2 Regional File, Box 2130, File 6000, Report of the Commanding General on the Buna Campaign, (Undated, ?? spring 1943)

${ }^{75}$ Bergerud, Touched with Fire, pp.366-67

${ }^{76}$ RG 165, War Department, 'P' File, Box 1203, MIS, Intelligence Bulletin, Volume 1, No.9, May 1943; also see Milner, Victory in Papua, pp.197, 255

${ }^{77}$ Milner, Victory in Papua, p.175

${ }^{78}$ MHI, Papers of Robert Eichelberger, Typescripts of official correspondence, Headquarters I Corps (US Army) to Major-General R.K. Sutherland, 31 December 1942

${ }^{79}$ RG 226, OSS, Research and Analysis Branch Divisions, Intelligence Reports, Box 936, War Department Technical Manual, Handbook on Japanese Military Forces, 21 September 1942
} 
notable shortcomings which became apparent was a lack of initiative, and this often rendered troops unable to alter their methods when faced with the unexpected. General Vandegrift noted how 'the Japanese soldier displayed tenacity and willingness to die on the spot, but no capacity to take independent action to redeem his situation' ${ }^{80}$ Even when bayonet assaults and frontal counterattacks (Banzai charges) ended with the destruction of entire units, enemy forces adhered to their methods, and showed 'the tendency to follow a set doctrine without the ability to readjust' ${ }^{81}$

The adversities faced in combat also led to a deterioration in combat efficiency. Captured diaries revealed credible signs of demoralization when faced with the superior weight of Allied weapons. A unit at Lunga point in Guadalcanal lost faith in its ability to win the battle when it was attacked with artillery and aircraft. ${ }^{82}$ In New Guinea, a soldier whose unit was under constant attacks by B-17 Flying Fortresses lamented, ‘isn’t God protecting the Imperial army?'. ${ }^{83}$ The Japanese were not the fearless fighters they had been portrayed to be, and when in adverse circumstances, they were 'just as scared and downhearted as any other person' ${ }^{84}$

Food shortages and the lack of medical supplies also had negative effects. At Guadalcanal, a soldier whose unit was on the verge of exhausting its rations explained how men were subsisting on green water grass and the sprouts of trees, with starvation and disease causing at least one casualty per day. ${ }^{85}$ POWs captured in New Guinea stated that almost half their comrades were overcome by malaria, and the shortage of water

\footnotetext{
${ }^{80}$ India Office Library and Records, British Library, London, L/WS/1/760, Combined Operations Headquarters, Bulletin No.Y17, 'Lessons Learned from the Guadalcanal Operations', (Summary of the Final Report by the Commanding General, $1^{\text {st }}$ US Marine Division), 15 December 1943

${ }^{81}$ RG 165, War Department, 'P' File, Box 1203, MIS, Intelligence Bulletin, Volume 1, No.9, May 1943

${ }^{82}$ RG 165, War Department, 'P' File, Box 403, Combat Intelligence Center South Pacific Area, Item No.167, Personal Diary, 2 June to 4 October 1942

${ }^{83}$ RG 165, War Department, 'P' File, Box 1232, Allied Air Forces, Southwest Pacific, Intelligence Summary No.78, 17 February 1943

${ }^{84}$ RG 165, War Department, 'P' File, Box 472, JICPOA, Bulletin 14-12, Japanese Land Forces, No.4, 31 December 1942

${ }^{85}$ RG 165, War Department, 'P' File, Box 403, Combat Intelligence Center South Pacific Area, Item No.444, Diary taken at Kokumbona, Guadalcanal, January 28-31, 1943
} 
purifying tablets meant that soldiers had to drink contaminated water. ${ }^{86}$ The turning tide of the war placed US intelligence in a better position to make an objective assessment of the IJA’s effectiveness.

At the same time, due attention was paid to indications that Japanese troops continued to possess tenacity. A MIS bulletin issued in January 1943 explained how the IJA's training was based on the theory that troops should be prepared to operate in undeveloped country without the advantages of motorized transport or heavy weaponry. ${ }^{87}$ For this reason, soldiers were in a state of physical fitness at an early stage of their military education, and able to perform virtually all types of field maneuvers. Soldiers also showed an unquestioned loyalty to their nation's cause, as revealed by an extract from a captured diary:

'I am glad to participate in this great mission as a Japanese. I am sure that the dawn of Greater East Asia is near. Morale is high and my belief in ultimate victory is firm. I shall never give in until the enemy is destroyed. [Our] country is God's country and I am son of God, hence I shall fear nobody. I shall smilingly undertake this great mission. Long live the Emperor' ${ }^{88}$

The most significant indication of high morale among Japanese soldiers was their adamant refusal to lay down their arms, even when faced with impossible odds. The IJA's code of practice dictated that to die in battle was the greatest honor, while to surrender was the ultimate disgrace. A lieutenant serving with the Inouye unit at Guadalcanal wrote in his diary, 'if we do not succeed in the occupation of these islands, no one should expect to return alive to Japan' ${ }^{89}$ Beleaguered troops preferred to commit suicide rather than allow themselves to be taken prisoner. ${ }^{90}$ In the Solomons, only eightyfour troops surrendered, and less than two-thirds did so voluntarily. The remainder were

${ }^{86}$ UKNA, WO 208/1448, Extract from ATIS, SWPA Interrogation Report No.30, Serial No.42, dated 2 February 1943, and No.35, dated 24 February 1943

${ }^{87}$ RG 165, War Department, 'P' File, Box 1203, MIS, Intelligence Bulletin, Volume 1, No.5, Part 1: Japan, Section 3, January 1943

${ }^{88}$ UKNA, WO 208/1446, ATIS, SWPA, Information about the Japanese, 14 June 1943

${ }^{89}$ RG 165, War Department, 'P' File, Box 403, Combat Intelligence Center South Pacific Area, Item No.239, Supplement No.1, War Diary Captured at Guadalcanal, Owner: $2^{\text {nd }}$ Lieutenant Hiroshi Yokota (Inouye Unit), 18 February to 22 October 1942

${ }^{90}$ RG 165, War Department, 'P' File, Box 1203, MIS, Intelligence Bulletin, Volume 1, No.3, Part 2: Japan, Section 1: The Burma Campaign, November 1942 
too sick or wounded to have any control over their fate. ${ }^{91}$

As the Allies captured their first handful of POWs, interrogations of captured soldiers provided further proof that they had been inculcated with the belief that surrender entailed dishonor. In fact, surrender was tabooed to the extent that the contingency was not recognized by Japanese military authorities. ${ }^{92}$ The majority of POWs stated that their greatest motivation for avoiding surrender was not their fear of betraying their Emperor and nation, but the danger that their families would be humiliated. ${ }^{93}$ Many POWs also feared social ostracization. A POW from Buna refused to let his family know his whereabouts, since that was 'the greatest shame imaginable'. ${ }^{94}$ Another prisoner expressed fears of facing court martial and execution. ${ }^{95}$ The evidence provided an example of the thinking that prevailed within the IJA, and highlighted the formidable obstacles that precluded larger numbers of Japanese troops surrendering.

Thus, by the early part of 1943, the spate of limited victories against the IJA in the Solomons and New Guinea provided the US Army and Marine Corps with a better amount of intelligence with which to formulate a more complex view of the Japanese army than they had previously. Japanese forces showed that their shortage of modern weapons, and the lack of flexibility in tactical methods, had a number of negative effects on their performance. At the same time, encounters with the enemy continued to reveal that it had a visible level of tactical skill at hampering the Allied advance. Although their morale showed signs of faltering, Japanese soldiers clearly demonstrated that their willingness to keep fighting remained largely unbroken. The image of the Japanese was therefore one of an enemy who could be defeated, but with a substantial effort.

${ }^{91}$ Miller, Guadalcanal, p.311

${ }^{92}$ RG 165, War Department, 'P' File, Box 2313, MIS, Tactical and Technical Trends, No.10, 'Japanese Prisoners of War', 22 October 1942

${ }^{93}$ U. Straus, The Anguish of Surrender: Japanese POWs of World War II (Seattle: Washington UP, 2003), pp.51-52

${ }^{94}$ RG 165, War Department, 'P' File, Box 321, ATIS, POW Interrogation Report No.29, M. Yamaguchi, 1 February 1943

${ }^{95}$ RG 165, War Department, 'P' File, Box 321, ATIS, POW Interrogation Report No.54, R. Inagaki, 14 April 1943 


\section{Implications for the development of tactical methods}

The initial counter-offensives against the IJA at Guadalcanal and New Guinea were often conducted with a vague idea of how enemy forces fought in defensive operations. Intelligence on Japanese fighting capabilities therefore did not influence the development of tactical doctrine during late 1942. On the contrary, the encounters enabled US forces to gain some badly needed information. Commanders in the US army and marine corps learned two important lessons concerning tactical doctrine. First, heavy armaments such as artillery, mortars, armor and close air support, were effective for overcoming Japanese forces that were insufficiently equipped. Second, and of equal importance, US infantry units needed perfect their methods in order to counter the Japanese soldier's rapid movements in the jungle, as well as eliminate enemy troops who stubbornly continued to resist. By mid-1943, however, US army intelligence services were playing an active role in disseminating the tactical lessons learned from the preliminary victories against the IJA. Action reports prepared by field commanders were regularly disseminated through intelligence publications, both in Washington and in the Pacific theaters.

During the opening stages of the Pacific War, the effectiveness of US military doctrine remained untested. The influence of combat experience against the IJA needs to be examined against the wider background in which American tactical ideas developed prior to the conflict. Army doctrine tended to rely on technology and firepower. The 1941 Field Service Regulations (FSR), while designating the infantry as the main arm, stipulated, 'no one arm wins battles. The combined action of all arms and services is essential to success'. ${ }^{96}$ Greater attention was paid to a war of movement, although emphasis was still on the attack and defense of organized positions. ${ }^{97}$ The main problem was that the War Department made minimal efforts to integrate the combined arms doctrine into a coherent practice. Lieutenant-Colonel Chynoweth, who served on the General Staff at one point, wrote on the essence of the problem: 'the General Staff has

\footnotetext{
${ }^{96}$ Drea, Service of the Emperor, p.61

${ }^{97}$ J. Luvaas, 'Buna: a Leavenworth Nightmare', in C.E. Heller and W.A. Stofft (eds), America's First Battles, 1776-1965 (Lawrence, KA: Kansas UP, 1986), p.187
} 
quite frequently failed to make the basic unifying decisions which would serve to coordinate the arms'. ${ }^{98}$ An army-wide training program did not exist until $1941 .{ }^{99}$

When the US army entered the war against Japan, its infantry force did not have an adequate number of skilled troops. At levels below the regiment, the bulk of the fighting was often carried out by a small number of riflemen. Although the Basic Field Manual: Jungle Warfare (FM 31-20) provided practical information on the matter, it did not anticipate situations where US forces needed to overcome enemy defenses. ${ }^{100}$ Although doctrine had stressed frequent movement and coordination of arms, US troops were not trained to carry out such moves. Major-General Edwin Harding, commanding the $32^{\text {nd }}$ Division, recalled that his troops 'had no opportunity to work through a systematic program for correcting deficiencies'. ${ }^{101}$ GIs were hesitant to advance unless enemy defenses had been subjected to overwhelming bombardment. During the stalling of the Buna operation, G-3 inspectors reported to MacArthur that the soldiers preferred to kill enemy troops at a distance, or 'have aircraft, mortars or artillery do the job for them'. ${ }^{102}$

The US Marine Corps faced similar problems. The majority of personnel passed through the officer-candidate school at Quantico, VA, where they received basic infantry training. However, for education on tactics, the marines depended upon the specialist schools run by the Army and Navy. Because the pre-war marine corps was a small institution that did not require a large number of technical specialists, it did not have an impetus for creating its own schooling system. ${ }^{103}$ Even in 1942, when rapid mobilization brought the Fleet Marine Force to a size of full three divisions, the marines were struggling to ensure proper access to specialist schools. The Corps was 'small, badly equipped,

\footnotetext{
${ }^{98}$ D.E. Johnson, Fast Tanks and Heavy Bombers: innovation in the US Army, 1917-1945 (Cornell, NY: Ithaca UP, 1998), p.182

${ }_{99}$ Odom, After the Trenches, p.204

${ }^{100}$ Luvaas, 'Buna', pp.188-89

${ }^{101}$ Milner, Victory in Papua, p.133

102 J.F. Shortal, Forged by Fire: Robert L. Eichelberger and the Pacific War (Columbia, SC: South Carolina UP, 1987), p.45

${ }^{103}$ A.R. Millett, Semper Fidelis: History of the Unites States Marine Corps (NY: Free Press, 1980), pp.361-62
} 
inappropriately employed, and in organizational chaos'. ${ }^{104}$ Most of the marines who served during the war went into battle having mastered few skills for ground warfare operations, aside from firing a rifle, and they were forced to learn about tactical field maneuvers while in combat.

When US forces began arriving in Australia during spring 1942, efforts to improve their efficiency were problematic, mainly because the majority of personnel were inexperienced. The $32^{\text {nd }}$ Division was drawn from the National Guard, and substantial time was needed to absorb and train the draftees before the division could operate efficiently. ${ }^{105}$ In September 1942, after Eichelberger inspected the division, he informed MacArthur that its combat capabilities were 'barely satisfactory', and it was not sufficiently trained to fight the Japanese 'on equal terms'. ${ }^{106}$ The main Allied objective until summer 1942 was to defend Australia, and plans for counter-offensives in New Guinea were not drawn until August. Consequently, the $32^{\text {nd }}$ Division received no training for jungle warfare. A new program was introduced, where the main emphasis was on developing physical fitness and stamina. Soldiers also learned the techniques of scouting and patrolling. Even then, American troops in the Pacific struggled to figure out the rules of the task they faced, because 'no one really knew how to fight'. ${ }^{107}$ The Buna campaign showed the extent to which American troops were not prepared for battle. Most units deployed with only five weeks of proper training. One soldier told Eichelberger that in twenty months of service, he had experienced only one night exercise, and asked how he could be expected to be proficient in night patrolling against the Japanese. ${ }^{108}$ Officers in the $32^{\text {nd }}$ division learned about jungle fighting 'the hard way', and had 'to write their own book' on the lessons learned. ${ }^{109}$

Nevertheless, commanders in the Pacific theaters were well-placed to identify the

\footnotetext{
${ }^{104}$ Bergerud, Touched with Fire, p.152

${ }^{105}$ Luvaas, 'Buna', p.191

${ }^{106}$ R.L. Eichelberger, Jungle Road to Tokyo (London: Odhams, 1957), p.35

${ }^{107}$ Bergerud, Touched with Fire, p.148

108 J. Luvaas (ed), Dear Miss Em: General Eichelberger's War in the Pacific, 1942-1945 (Westport, CT, 1972), p.61

${ }^{109}$ MHI, Papers of William H Gill, Transcript of Interview
} 
prerequisites for conducting successful operations against the IJA. American military traditions demanded that officers take a pragmatic view of the battlefield situation, and devise tactics that could defeat the enemy without incurring excessive losses. ${ }^{110}$ US forces were also staffed by competent personnel. In the marine corps, most recruits had volunteered, and had a high degree of motivation. Many of them had worked on farms or in warehouses, and were familiar with physical labor, as well as the use of machinery, both of which proved essential when fighting in the Pacific theaters. ${ }^{111}$ Senior leaders proved to be 'unusually good tacticians'. The US army had an efficient officer education system. At the Command and General Staff College in Ft. Leavenworth, KA, the curriculum was geared to prepare officers for the functions they needed to carry out at the all levels. Graduates were taught to 'think, to analyze and to decide realistic courses of action', and the US army was equipped with an officer corps who had the intellectual capacity to develop an effective set of methods. ${ }^{112}$ The main task facing field officers was to determine how the IJA fought, and thereafter apply the doctrine of combined arms in a manner that was suitable for defeating the enemy. In order to apply the lessons of encounters with the Japanese, the Americans used 'the standard tools of military intelligence'. ${ }^{113}$ Battlefield encounters with the Japanese were analyzed to discover what had gone wrong or right.

Encounters in the Solomons and New Guinea showed that before US forces could fight with any prospect of success, one of the first steps was to build up a sufficient level of efficiency among infantry units. Soldiers had to be in good physical condition, and master the methods of executing small unit tactics. While US marines proved themselves superior to the Japanese in actual combat, their victory at Guadalcanal was by no means easy. General Vandegrift reported that the most notable shortcoming among his units was 'inadequate physical training' ${ }^{114}$ In order to remedy this fault, soldiers had to be trained

\footnotetext{
${ }^{110}$ Bergerud, Touched with Fire, pp.161, 179

${ }^{111}$ Ibid., pp.153-59

${ }^{112}$ Drea, Service of the Emperor, p.72-73

${ }^{113}$ S.P. Rosen, Winning the Next War: innovation and the modern military (Ithaca, NY: Cornell UP, 1991), pp.31-32

${ }^{114}$ RG 127, Records of the US Marine Corps, World War II Operations, Box 39, First Marine
} 
to march long distances through unfavorable terrain. ${ }^{115}$ From a logistical point of view, the launching of the North Africa landings meant that US forces could not receive reinforcements. In early December, following months of an extended campaign, there were no 'experienced fresh troops', with the majority of units succumbing to debilitation and battle weariness. ${ }^{116}$

In defensive operations, US forces needed to neutralize the Japanese by making use of their superior artillery fire. Officers from Guadalcanal agreed, almost unanimously, that heavy weapons, particularly the mortar, were 'vital to defense'. ${ }^{117}$ Because Japanese forces were capable of penetrating gaps as narrow as fifteen yards, it was 'important to co-ordinate automatic weapons fire to cover the entire front of a defensive position' Experiences at the Tenaru river and on Edson's ridge engendered a confidence that marine rifle units in well-prepared positions and behind barbed wire obstacles could defeat Japanese attacks, even when heavily outnumbered. ${ }^{118}$

Infantry units also had to conduct an aggressive patrol of their environs, and eliminate enemy troops by engaging in close-range combat. Commenting on the successful attempts at repelling Japanese attacks on Henderson Field, the Third Marine Division opined, 'a force in defense may considerably confuse and deter an outflanking force by ambushing them with patrols'. ${ }^{119}$ Emphasis was also placed on night training, and 'up to 50 percent of available training time [was to] be thus utilized'. ${ }^{120}$ On numerous occasions, experiences showed that, instead of seeking out Japanese forces in the open country, the most effective method was to establish a perimeter cordon, protected by barbed wire and

Division, Division Commander's Final Report on Guadalcanal Operations, Phase III: Organization of the Lunga Point Defenses, 10-21 August

${ }^{115}$ Miller, Guadalcanal, p.318

${ }^{116}$ Ibid., p.217

${ }^{117}$ MHI, War Department, MIS, Military Reports on the United Nations, No.3, 'Lessons from Guadalcanal', 15 February 1943 (hereafter, 'Lessons from Guadalcanal')

${ }^{118}$ Frank, Guadalcanal, p.262

${ }^{119}$ RG 127, Records of the US Marine Corps, World War II Subject File, Box 28, Headquarters Third Marine Division, Fleet Marine Force (San Diego), Lessons from Japanese Tactics, 30 November 1942

120 'Lessons from Guadalcanal' 
noisemakers to alert the defenders. ${ }^{121}$ US servicemen also had to be persuaded to overcome their fears of enemy attacks. Major Ben Northbridge, commanding the $2^{\text {nd }}$ battalion, $164^{\text {th }}$ infantry regiment, remarked, 'if I could train my men over again, I would put officers and men in slit trenches and drop bombs nearby to overcome fear'. ${ }^{122}$

In offensive operations, US forces needed to undertake a laborious and slow effort. While infantry units often spearheaded the advance, without proper fire support, they could not breach enemy perimeters without suffering heavy casualties. The use of artillery, tanks and tactical air units proved 'as essential in jungle warfare as in open warfare'. ${ }^{123}$ Nevertheless, field commanders needed to gain sufficient experience before they could fully understand the value of heavy weaponry. Prior to the Solomons campaign, officers entertained doubts whether it was practical to employ $106 \mathrm{~mm}$ guns in the jungle, owing to their lack of mobility. ${ }^{124}$ Encounters at Guadalcanal quickly proved that the weapons had 'a definite place in future operations'. The initial attack on Buna failed because troops were not provided with weapons that could defeat Japanese bunkers. ${ }^{125}$ Tanks had not been brought to the forward lines, and the Americans carried out the attack with only one howitzer, with insufficient reserves of ammunition. ${ }^{126}$ The operation proved that artillery was useful in reducing Japanese bunkers, and thereafter, all infantry units were provided with high-caliber guns. Close air support was also a valuable weapon, especially in areas where the terrain consisted of tall mountains and deep gorges. ${ }^{127}$ Artillery units could not deliver fire to the reverse slopes, where the Japanese often chose to build their

${ }^{121}$ Bergerud, Touched with Fire, pp.381-85

${ }^{122}$ MML, RG 30, Papers of Richard K Sutherland, Box 26, Folder 12, Government Printing Office, Fighting on Guadalcanal, Commentary by Major Ben Northbridge, $2^{\text {nd }}$ battalion, $164^{\text {th }}$ infantry, 1943

${ }^{123}$ RG 127, Records of the US Marine Corps, World War II Subject File, Box 58, General Jens A Doe, (US Army) Notes on Jungle Warfare, No.1, 27 April 1943

${ }^{124}$ RG 127, Records of the US Marine Corps, World War II Operations, Box 39, First Marine Division, Division Commander's Final Report on Guadalcanal Operations, Phase IV, (hereafter, Guadalcanal Operations, Phase IV)

${ }^{125}$ Mayo, Bloody Buna, pp.107-8, 182

${ }^{126}$ MHI, Papers of James F Collins, Final transcript of oral history, Conversations between General James F Collins and Colonel Wade Hampton, in series US Army Military History Research Collection; also see Milner, Victory in Papua, pp.246, 374-75.

${ }^{127}$ UKNA, WO 208/2263, WOWIS, No.195, 'Air Support of Ground Units in the Southwest Pacific’ (Extract from a report by the MIS), 12 May 1943 
positions.

At the same time, infantry units had to develop effective techniques of advancing against the IJA's lines and mop up the remnants of its opposition. Aerial bombing and gunfire were not effective in some situations, especially when the Japanese fortified themselves in natural features such as caves, as they did at Gavutu and Tanambogo. ${ }^{128}$ Nor did bombardment work on gun emplacements unless the bombs and high explosive shells landed directly, as 'a lucky hit'. In order to ensure that enemy defenses were properly neutralized, infantry units had to physically occupy the ground. Lieutenant-Colonel Carlson, from Second Marine raider battalion, suggested that attacks be carried out against the rear and flanks of Japanese positions, so that the defenders could be taken by surprise. ${ }^{129}$ All divisions at Guadalcanal agreed that the campaign taught how soldiers needed to operate independently in small units, since the rugged terrain did not permit the movement of massed forces. ${ }^{130}$ US troops also needed to overcome their enemies by using light infantry weapons such as the hand grenade. ${ }^{131}$ Success depended upon individual soldiers and NCOs acting 'promptly and intelligently when confronted with a situation’.

Encounters in New Guinea offered similar lessons. Infantry units were initially trained only for frontal attacks, which proved costly. ${ }^{132}$ Eichelberger solved the problem by replacing the leadership, including General Harding, and devising a plan whereby patrols were to scout enemy territory, and to call in mortar fire upon discovering a bunker. ${ }^{133}$ While the arrival of tanks enabled the attackers to take the initiative, ${ }^{134}$ advances could be

\footnotetext{
${ }^{128}$ RG 496, General Headquarters Southwest Pacific Area, Box 731, Division Commander's Final Report on Guadalcanal Operation, Phase II, (undated, ?? autumn 1942)

${ }^{129}$ UKNA, WO 208/1501, Extracts from Mopping Operations of US $2^{\text {nd }}$ Marine Raider Battalion, 4 November to 4 December 1942

${ }^{130}$ Miller, Guadalcanal, p.307

${ }^{131}$ MML, RG 30, Papers of Richard K Sutherland, Box 26, Folder 12, Government Printing Office, Fighting on Guadalcanal, Commentary by Colonel B.E. Moore, Commanding Officer, $164^{\text {th }}$ Infantry, 1943

${ }^{132}$ Shortal, Forged by Fire, p. 45

${ }^{133}$ Milner, Victory in Papua, pp.245-46

${ }^{134}$ Ibid., pp.262-63
} 
made only by 'killing and digging out the Japanese occupying each bunker', a task that entailed 'a slow, tedious and difficult process'. ${ }^{135}$ The operations 'conclusively' demonstrated that US forces needed to undertake a more 'detailed, extended, and thorough training of the individual soldier and the squad, section and platoon leaders'. Frontal attacks were to be avoided, and Japanese operations had shown that attacks from the flank and rear provided 'the best opportunity for success'. ${ }^{136}$

Because supporting arms and infantry units had important roles to carry out, close cooperation was essential. The War Department noted how even in units commanded by competent officers, a common mistake was to neglect setting up a definite arrangement between air and ground units for mutual support, which often resulted in an 'ineffectiveness of both'. ${ }^{137}$ One of the areas where close coordination proved essential was in tank operations. At Guadalcanal, tanks were effective in breaking through Japanese defenses, but they had to operate 'at slow speed and with extremely close infantry support' so that they could be adequately protected against enemy anti-tank parties. ${ }^{138}$ At Cape Endaiadere and Giropa Point, when tanks were not protected by foot soldiers, they were exposed to Molotov cocktails, hand-placed anti-tank mines and enemy personnel jumping onboard with anti-tank bombs. ${ }^{139}$ At Sanananda, the Japanese proved 'astonishingly accurate in his anti-tank small arms fire'. Against such an opponent, tanks needed sufficient armament and armor to enable them to 'close with the enemy'.

Infantry units needed a proper knowledge of the battles they were fighting. A meticulous surveillance was essential to gain accurate intelligence on enemy positions. The main problem was that, owing to the IJA's skill in concealing its positions and the movement of its troops under thick jungle vegetation, aerial reconnaissance was not entirely reliable.

\footnotetext{
${ }^{135}$ RG 165, War Department, 'P' File, Box 2313, MIS, Tactical and Technical Trends, No.17, 'Tactics on Guadalcanal and New Guinea', 28 January 1943

${ }^{136}$ Shortal, Forged by Fire, p.61

${ }^{137}$ RG 407, Records of the AGO, World War II Operations Reports, Box 10296, File 337-2.2, War Department, Common Mistakes in Operations, 6 February 1943

${ }^{138}$ Guadalcanal Operations, Phase IV

${ }^{139}$ RG 165, War Department, 'P' File, Box 2271, Allied Land Forces in Southwest Pacific Area, Land Headquarters, AFV Training Memorandum No.2, (based on information received from New Guinea), March 1943
} 
In the Solomons, information on Japanese troop strengths was patchy, and 'all too frequently wrong', showing either an exaggeration or underestimation. ${ }^{140}$ Nor did the marines have good maps of the island, and the deficiency was 'never remedied throughout the campaign'. ${ }^{141}$ Prior to the Buna operation, General Charles Willoughby, head of MacArthur's G-2, calculated that, owing to its previous losses, the IJA only had 1,500 defending troops, when the actual figure was over fivefold. ${ }^{142}$

Attacking forces therefore had to obtain the information through their own efforts, without relying excessively on their intelligence units. A constant reconnaissance was necessary in order to stay updated on the enemy situation. At Guadalcanal, the junior officers and NCOs were not experienced, and Vandegrift criticized the initial failure of all units to patrol their fronts and flanks properly. ${ }^{143}$ As the campaign progressed, marine patrols learned to work as a team, whereby two members conducted a scout, while the third remained hidden and kept a lookout for enemy movements. ${ }^{144}$ Officers noted how the development of small unit tactics, at the squad and platoon level, was essential in order to develop the necessary methods for reconnoitering. ${ }^{145}$ Patrols needed to observe Japanese positions for extended periods, 'stalking' them, and await for moments when enemy troops emerged to prepare food or carry out construction work. ${ }^{146}$ In order to operate effectively, patrols needed complete details of the terrain. During the approach to Buna, the $128^{\text {th }}$ regiment had little topographical intelligence. ${ }^{147}$ As a result, patrol leaders were unable to note their own locations, and the attacking force could not conduct

\footnotetext{
${ }^{140}$ Frank, Guadalcanal, p.50

${ }^{141}$ Miller, Guadalcanal, p.45

${ }^{142}$ Shortal, Forged by Fire, p.41

${ }^{143}$ Miller, Guadalcanal, p.71

${ }^{144}$ RG 494, MIDPAC, Box 64, Headquarters Force 9156, Notes on the Solomon Islands, 13 November 1942

${ }^{145}$ MML, RG 30, Papers of Richard K Sutherland, Box 26, Folder 12, Government Printing Office, Fighting on Guadalcanal, Commentary by Colonel Merritt A Edson, Commanding Officer, Fifth Marines, 1943

${ }^{146}$ MML, RG 30, Papers of Richard K Sutherland, Box 26, Folder 12, Government Printing Office, Fighting on Guadalcanal, Commentary by Lieutenant-Colonel Frank Richards, Commanding Officer, $1^{\text {st }}$ Battalion, $164^{\text {th }}$ Infantry, 1943

${ }^{147}$ RG 407, Records of the AGO, World War II Operations Reports, Box 9046, File 332-2, Headquarters $32^{\text {nd }}$ Infantry Division (Office of the Assistant Chief of Staff, G-2), Report of Action, Papuan Campaign, 3 April 1943
} 
a proper reconnaissance of enemy dispositions and replacements. Front-line troops often had 'no trustworthy knowledge of Japanese positions', and the information was not obtained until actual attacks were conducted. ${ }^{148}$

By the early part of 1943, US ground forces in the Pacific theaters gained a competent knowledge of the measures they needed to undertake. The army and marine corps succeeding in taking the initial steps towards applying their doctrine of combined arms operations in practice, and adapting them to meet the challenges posed by the IJA. The G-3 report on the Buna campaign concluded that the operation did not reveal any new principles of warfare; however, the nature of the terrain and the enemy dispositions 'necessitated some novel applications of well known principles' ${ }^{149}$

The main task facing US forces was to disseminate the lessons of their initial victories. The acquisition of a better knowledge of how to defeat Japanese meant that intelligence publications on the IJA army began to include a substantial amount of material on the subject. Large amounts of fire power were likely to prove effective in reducing enemy defenses. At the same time, field artillery units needed to synchronize their fire so that advancing the infantry could be covered. At Guadalcanal, guns were 'highly effective in destroying stubborn enemy resistance', mainly because liaison officers provided intelligence that aided the adjustment of artillery so they could hit smaller targets such as machine guns, mortars, and dug-in pockets of resistance. ${ }^{150}$ The most salient lesson, nevertheless, was that US forces could not rely on any set procedures, and ingenuity was essential. Officers in the $1^{\text {st }}$ Amphibious Corps suggested that enemy forces should be countered by using some of their methods, such as booby traps and the ambushing of trails. ${ }^{151}$ Some of the Japanese soldier's strengths, such as his tendency to fight to the

\footnotetext{
${ }^{148}$ Eichelberger, Jungle Road, pp.50-51

${ }^{149}$ RG 165, War Department, G-2 Regional File, Box 2153, File 6910, Report of the Commanding General, Buna Forces, Annex 3, G-3 Report

${ }^{150}$ MHI, War Department, MIS, Military Reports of the United Nations, No.8, 'Employment of field artillery on Guadalcanal', 15 July 1943

${ }^{151}$ RG 226, OSS, Research and Analysis Branch Divisions, Intelligence Reports, Box 406, Japanese Jungle Tactics and Suggested Counteraction, based on note prepared by Major Kenneth D Bailey, (USMC), 29 March 1943
} 
death, and the manner in which he conducted operations without concern for losses, could play into the hands of American troops, so long as they were properly trained, and inducted with a confidence in their 'superior ability to outthink, outshoot and outfight' their opponent. ${ }^{152}$ Infantry units also devised ad hoc ways to for reduce enemy defenses. A marine officer noted how, in situations where the Japanese took cover in dugouts and offered prolonged resistance, a bucket of gasoline thrown into the entrance, followed by a hand grenade to ignite an explosion, 'generally produced results'. ${ }^{153}$ Against larger dugouts, where attacking parties were shot as they entered the tunnels, recourse was had to using 'sufficient dynamite at the tunnel entrance to partially cave it in'. When the air inside got bad, the Japanese often emerged.

More importantly, the lessons needed to be integrated into a theater-wide system for training, so that army and marine corps personnel could prepare for the challenges they faced. Jens Doe, who commanded the $1^{\text {st }}$ infantry battalion at Sanananda, asserted that all units needed to use reports on enemy tactics to 'the fullest extent', so that training could take place with a realistic simulation of battlefield conditions. ${ }^{154}$ Yet, inter-service rivalries continued to hinder the sharing of lessons between the South Pacific and SWPA. For example, the US Army's lessons from Buna did not circulate to the marines in the Solomons. The Navy did not have a clear idea of the difficulties which Japanese defenses could pose, and deployed two untested National Guard divisions at New Georgia. ${ }^{155}$ The landing party's casualties were higher than the $32^{\text {nd }}$ division's losses at Buna.

Top military commanders in the Pacific theaters also continued to voice concerns that US forces had yet to achieve an adequate level of efficiency. The difficulties faced in neutralizing Japanese resistance convinced Eichelberger that all units heading to the front

\footnotetext{
${ }^{152}$ RG 165, War Department, G-2 Regional File, Box 2129, File 6000, Lieutenant-Colonel C.P. Van Ness (US Marine Corps), Exploding the Japanese Superman Myth, Undated, ?? spring 1943

${ }^{153}$ RG 127, Records of the US Marine Corps, World War II Subject File, Box 54, Japanese Tactics and Equipment, No.3, (Undated, ?? autumn 1942)

${ }^{154}$ RG 127, Records of the US Marine Corps, World War II Subject File, Box 58, Notes on Jungle Warfare, No.1: prepared by General Jens A Doe, (US Army), 27 April 1943

${ }^{155}$ Bergerud, Touched with Fire, p.225
} 
needed to undergo an extensive training program. ${ }^{156}$ Yet, shortly after Buna, General George Kenney, MacArthur's chief of air staff, opined that troops engaging in the Papuan campaign were not trained in close-range combat, because 'the school books haven't been teaching this game'. ${ }^{157}$ Unfortunately, the problem persisted until the later stages of the campaign, mainly because the large influx of new arrivals, coupled with the need to deploy troops to the front at short notice, placed a strain on the system. The Headquarters of the US Army Forces in the South Pacific even stipulated, 'training will be so conducted as not to interfere with the tactical mission of any unit'. ${ }^{158}$ The situation caused periodic problems. For example, following the Bougainville campaign, the $37^{\text {th }}$ Division recommended, 'training in scouting and patrolling and ground reconnaissance should be more detailed and thorough' ${ }^{159}$ Nevertheless, as the Pacific War progressed, both the army and marines corps learned how to develop the necessary methods for defeating the IJA. The encounters at Guadalcanal and Buna provided the first opportunities for the Americans to test their doctrines against the Japanese. While the initial counter-offensives in the Pacific theaters were not conducted with a full knowledge of Japanese tactics on the defense, the situation improved as a result of combat experience. Encounters with the enemy showed US forces the weaknesses they need to remedy, as well as the strengths that contributed to their success.

\section{Conclusion}

The evolution of US intelligence assessments during the opening stages of the Pacific War demonstrated how the Americans needed to fight the IJA in order to determine its fighting capabilities and the countermeasures necessary to defeat it. Prior to outbreak of hostilities in December 1941, the Americans did not have a reliable basis for making a realistic assessment. The IJA's problems in winning its war in China gave rise to the

\footnotetext{
${ }^{156}$ Shortal, Forged by Fire, pp.61, 69-71

${ }^{157}$ RG 127, Records of the US Marine Corps, World War II Operations, Box 47, Headquarters US Marine Corps, (Washington), Excerpts from a letter from General Kenney to General Arnold, 1 January 1943, and Memorandum for Colonel Riley, 5 February 1943

${ }^{158}$ RG 494, MIDPAC, Box 5, Headquarters USAFISPA, Training Memorandum No.6: Training Directive for Ground Forces, 21 August 1943

${ }^{159}$ RG 407, Records of the AGO, WWII Operations Reports, Box 10037, File 337.2, 37 ${ }^{\text {th }}$ Infantry Division, Lessons of Bougainville Campaign, 18 July 1944
} 
conclusion that it did not have the resources necessary to wage war against an Allied coalition. Under the circumstances, the Japanese had yet to prove their capacity to defeat their western rivals in combat, and the Americans were unlikely to see any reason to be alarmed over the IJA’s prowess.

The IJA's success in eliminating Allied military power from Southeast Asia during the early part of 1942, and the speed with which the Japanese conducted their operations, gave rise to the contention that US forces were confronting an enemy with superior martial qualities. Oftentimes, intelligence staffs, as well as military personnel, tended to exaggerate the IJA's capabilities, and credited it with a level of skill which it did not actually possess. The successes achieved by the marine corps and army in overcoming Japanese forces at Guadalcanal and New Guinea during late 1942 and the early part of 1943 enabled the Americans to develop a more realistic view. The main lesson drawn from the Allies' initial counter-offensives in the Pacific was that the IJA's combat capabilities were by no means superior, and its main weakness was a shortage of modern equipment, coupled with inadequate methods of their use. When faced by properly trained and equipped troops, the Japanese could be defeated. At the same time, the Japanese continued to demonstrate their capacity to put up a significant challenge. In offensive operations, enemy forces were adept at using surprise and mobility to outmaneuver the Allies. When defending its positions, the IJA demonstrated a visible level of skill at constructing positions that could withstand the effects of heavy bombardment, while its troops were prone to fight to the last man and round. Owing to their capacity to inflict delay and attrition on the Allies, the US army and marine corps continued to view the Japanese as a difficult opponent that could be overcome only with a substantial commitment of time and resources. The main effect of the intelligence obtained through the initial encounters with the IJA during 1942 and early 1943 was to introduce American military personnel to the challenges they were to face during their land campaigns in the Pacific theaters.

The information which the Americans gained on the Japanese army during the opening stages of the Pacific War also had an impact on the development of the tactical doctrine. 
The setbacks in the Philippines exposed a number of weaknesses which had to be remedied. Field commanders and soldiers alike were over-reliant on heavy armaments, which gave rise to a situation whereby infantry units did not have the skill to counter the Japanese soldier's rapid movements and to neutralize enemy defenses. The counteroffensives in the Pacific theaters during late 1942 were conducted with a vague idea of the challenges posed by the IJA's defensive tactics, and military personnel did not have substantial knowledge on the counter-measures they needed to adopt. The most important lesson to emerge was that US forces had to be prepared to undertake a laborious and slow effort if they were to overcome the Japanese. Because the IJA's defenses were built with a considerable level of resilience, adequate amounts of fire support had to be brought to bear in order to neutralize them. At the same time, the Japanese soldier's tendency to continue fighting until he was killed meant that foot soldiers were needed to physically occupy the positions and to clean up the remnants of enemy resistance. While the Americans had yet to perfect their methods of fighting the Japanese, their initial spate of limited victories enabled the US army and marine corps to gain a sufficient base of knowledge on the tactics they needed to develop. Thus, by the early part of 1943, US military personnel in the Pacific theaters had the combat experience they needed not only to formulate a realistic image of their opponent's combat capabilities, but also to develop the tactical methods that were necessary for defeating Japanese forces on the battlefield. 


\section{Map 1}

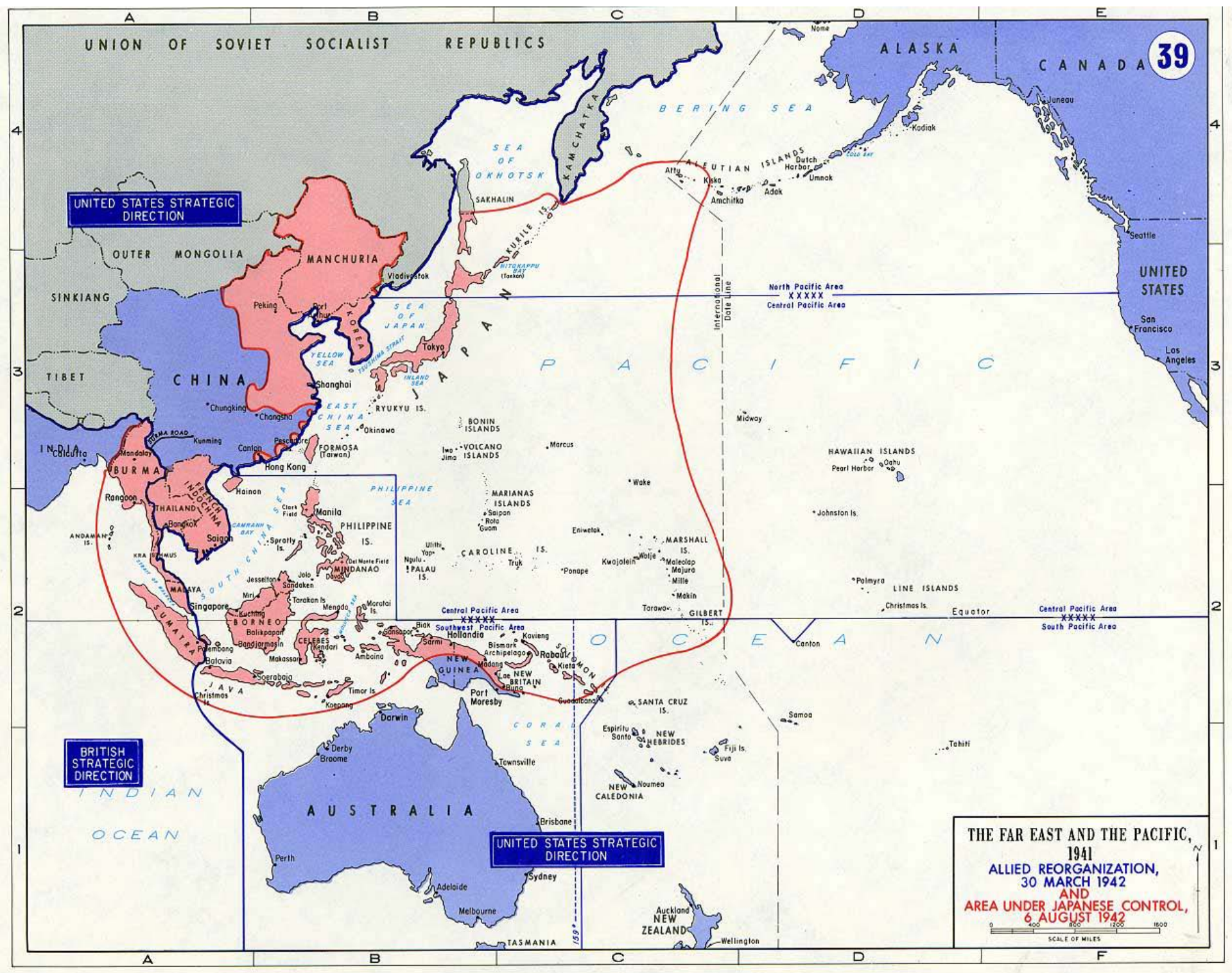

